\title{
Paideusis
}

\section{Open-mindedness Revisited: A Response to Cornel Hamm}

\section{William Hare}

Volume 1, Number 2, 1988

URI: https://id.erudit.org/iderudit/1073425ar

DOI: https://doi.org/10.7202/1073425ar

See table of contents

Publisher(s)

Canadian Philosophy of Education Society

ISSN

0838-4517 (print)

1916-0348 (digital)

Explore this journal

Cite this document

Hare, W. (1988). Open-mindedness Revisited: A Response to Cornel Hamm.

Paideusis, 1(2), 23-26. https://doi.org/10.7202/1073425ar

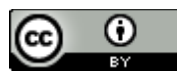

This document is protected by copyright law. Use of the services of Erudit (including reproduction) is subject to its terms and conditions, which can be viewed online.

https://apropos.erudit.org/en/users/policy-on-use/
This article is disseminated and preserved by Érudit.

Érudit is a non-profit inter-university consortium of the Université de Montréal, Université Laval, and the Université du Québec à Montréal. Its mission is to promote and disseminate research.

https://www.erudit.org/en/ 


\section{Discussions}

\section{Open-mindedness Revisited: \\ A Response to Cornel Hamm}

\section{William Hare, Dalhousie University}

I am grateful to Cornel Hamm for having taken the time to read and review my book so carefully [Paideusis, 1(1)]. Books are not always read diligently and fairly by reviewers. But I cannot find a single instance where Professor Hamm has distorted or misrepresented my meaning.

1. His first point of criticism relates to my discussion of the relationship between open-mindedness and commitment. I set out to expose some conceptual confusion in this quarter, but Hamm maintains that it is possible not to be conceptually confused and still hold that open-minded people lack commitment. This is true and I do not deny it. On p. 10 of In Defence of Open-mindedness, when I am dealing with the views of John Colbeck in this context, I say explicitly that one could ignore many values and ideals in pursuing certain goals. In other words, I do not dispute the empirical possibility of open-minded people neglecting the value of commitments. What I wanted to do, however, was to show that there is nothing in the notion of open-mindedness itself which precludes the having of commitments. But this is denied by Colbeck, for example, when he asserts that to be committed to impartiality is to be committed to not being committed. I think that has to be read as a conceptual claim, a confused one, and here the philosopher's task is to expose those tempting lines of thought which lead to its being made. Hamm suggest that I do not always argue for my own counter claim, and he bemoans my "frequent substitution of assertion and conceptual analysis for argument." I reject the contrast here between conceptual analysis and argument, for exposing conceptual confusion is one kind of argument. And in eliminating those considerations which lead people to believe that open-mindedness and commitment are incompatible, what reason is there it deny that a person can be prepared to revise the commitments which he or she has made?

2. Hamm's second objection arises in connection with the point I make in the chapter on elementary education that open-mindedness can enter into moral education. The remark which gets me into trouble is that, "we can surely claim that that teaching is openminded which seeks to stimulate and promote the child's development through the stages)." I am not a die-hard Kohlbergian, and if his theory has been demolished, fine. It does seem to me, however, that 
children do come to appreciate different kinds of reasons as relevant in morality as they grow up, and my point is that moral teaching could be thought of as open-minded to the extent that it sought to prevent children from getting stuck with one kind of moral reason too early. The teaching is open-minded in the sense that it aims at open-mindedness. This aim is to have children develop into adults who can think critically and reasonably about moral beliefs. If children cannot rationally assess moral views now, we can be actively on the lookout for the moment when this starts to be possible and try to encourage it. Incidentally, open-mindedness is not just a matter of revising our ideas. It is also a matter of being willing and able to entertain new ideas, and it is this aspect $I$ have in mind when I speak of keeping the child's mind open.

3. With respect to the argument in Chapter 3 , where I try to show the importance of open-mindedness about one's moral principles, Hamm finds more assertion than argument. Let us consider this charge with respect to my view that we ought to be prepared to consider making exceptions to our principles on occasion, a view which some moral philosophers reject. My strategy is to ask what their reasons are for denying exceptions, and it turns out that they hold, among other things, that allowing for the possibility of exceptions means that we are unprincipled, that we lack proper confidence in our views, that we are toying with doing something we should reject outright, that no one will be able to count on us, and that we put undue weight on unusual cases. Now if $I$ were engaged in assertion, I would simply reject these reasons out of hand and announce my own view. But in each case I explain carefully how these misunderstandings arise, for example, from the ambiguity in the notion of entertaining doubts. Having cleared away these misleading points, I go on the offensive and point out that we do, in fact, blame people on occasion for not having made an exception, that problems with our principles do arise in the practical context and presumably should not just be dismissed, and finally, a reductio argument, that if considering exceptions is evidence of a corrupt mind then Socrates displays one in the Crito. I do not believe the charge of mere assertion can be made to stick. It is itself a mere assertion.

4. In reviewing Chapter 6 concerning open-mindedness in administration, Hamm observes that I make the rather obvious observation that we must be prepared to modify our organizational commitment if over-riding considerations arise. I'm not sure if "obvious" is being used here in a pejorative way to suggest that the point is trivial, too obvious to be worth making. Hamm may simply mean that my point is obviously correct. In any event, the point needed to be made just because certain authors seem to think that being prepared to modify one's organizational commitments means that every decision will have to be constantly re-examined and nothing 
will ever by finally decided. I would agree that my point ought to be obvious, I am glad that it is seen to be so by some, but unfortunately it is missed by others. It seems to fall to the philosopher from time to time to remind people of the obvious.

5. It is true that I do simply assert that "students can be encouraged, directly and indirectly, to reflect on values and beliefs they are acquiring" in connection with the problem of the hidden curriculum. Hamm tells us that what needs discussion and argument is how students can thus reflect on values and beliefs when they are part of the hidden curriculum. He does not provide the discussion and argument either, and his emphasis on the word "hidden" may suggest that he finds my idea contradictory or at least paradoxical. Let me then elaborate. First, and this is a point 1 do make in the book, a hidden curriculum may itself encourage students to be critical about the beliefs and values being acquired. A hidden curriculum may not have the objectionable character outlined by Illich. A teacher may set an example of a person who reflects critically on assumptions and ideas generally taken for granted, and the students may pick this up. Moreover, particular courses could actually talk about the problem of the hidden curriculum and what its messages might be. Of course, as long as it remains hidden, we cannot talk about the content. But students can be helped to ask what the content might be. For example, students can be asked how far they agree that what is learned in school is all that is worth learning, and whether or not they think that schools do teach this idea.

6. Professor Hamm accuses me of being obscure and cryptic to the point of being unreadable. But his own account of one such allegedly obscure passage from Chapter 3, and indeed his general summary of the entire book, is so admirably accurate that I am encouraged to think that his criticisms must be exaggerated. I am not aware of there being unexplained references here or elsewhere, in fact I think I have faithfully tried to document every view being considered. Chapter 3, more than the others, does involve some fairly detailed study of recent work in general philosophy, in this case ethics, and not everyone will be familiar with the details of the debate. So there is some risk of appearing to speak to the "in" crowd. I tried to say enough about the views under discussion to make the chapter intelligible without forcing the reader to consult sources. This did mean, however, that some complex positions had to be compressed into manageable form. This is not a chapter to be casually skimmed, I agree. But I have not tried to be obscure. One point in partial mitigation is this. Open-mindedness ranges over the whole spectrum of beliefs, values and decisions, and therefore takes us into many different areas. For me, this is one of its great attractions and suggests to me that it is a very fundamental notion. But the result is that readers cannot expect to be as familiar with the york in some grees as they are with others. I(2), Spring, 1988 as they are with others. 
7. Finally, Hamm quoles a ten line passage from the chapter on open-mindedness in science and proceeds to raise some twenty two questions about it. That's two questions per line, and it almost persuaded me that Cratylus was right to believe that it was better to say nothing at all. I do not intend to deal with all of these questions seriatim but I will make some general comments about the passage cited. Joseph Schwab in The Teaching of Science as Enquiry (1962), drew a distinction between science as stable inquiry and science as fluid inquiry, a distinction which closely parallels Kuhn's distinction between normal science and revolutionary science. Schwab held that science teaching tended to reflect science as stable inquiry in which scientific claims were passed on as irrevocable. Here he used his famous phrase, a rhetoric of conclusions, to mean that the tentative is accepted as certain and the doubtful as undoubted. He argued for a new conception of science teaching in which students would learn to participate in a process of scientific discovery.

In my book I quote a line from Kuhn which indicates that he approved in general of the reforms being implemented in the teaching of science in the early 1960's, but also reveals a doubt as to whether facts in science teaching could be dispensed with in favour of learning to learn, i.e., acquiring methods of investigation, a distinction which had been introduced by another contributor to the debate. Kuhn concluded that science students would still have to "learn paradigms," and the significance of this remark is that Kuhn believes that learning paradigms is necessarily dogmatic. Now, of course, I agree that the contrast between facts and methods is one of those over- simplified distinctions which are all too common in educational theory and tend to lead us into either/or thinking. And my first point was simply that it is a great mistake to think that a course which attempts to teach facts is thereby closed-minded. Here Schwab's contrast between the irrevocable and the tentative is useful.

My own view is that Schwab is right to condemn the teaching of science as a rhetoric of conclusions just because many of our firm conclusions today will have to be abandoned tomorrow. When conclusions are taught dogmatically, (and I use "dogma" as I think Kuhn does to suggest that the claim is regarded as beyond question), this does not encourage the development of that attitude which will be needed when revision is called for. But Kuhn is also right to insist that students need to become acquainted with present-day conclusions, the facts as we see them. His error, as I see it, it to believe that such initiation must be dogmatic. I argue that it makes good sense to speak of an open-minded attitude towards the prevailing paradigm. I say that we should resist dogmatic initiation because dogmatists are not disposed to revise their views, and the time sometimes comes when revision is necessary. 